\title{
ВИКОРИСТАННЯ БІОРЕЗОНАНСНИХ ТЕХНОЛОГІЙ В УМОВАХ РАЙОННОЇ ПОЛІКЛІНІКИ
}

\author{
оБ. С. Майнош
}

\section{Чортківська центральна клінічна районна лікарня}

РЕЗЮМЕ. Мета - зробити короткий огляд розвитку і трансформації рефлексотерапії в біорезонансну діагностику і терапію в умовах районної поліклініки. На конкретному прикладі показати окремі діагностичні і терапевтичні можливості вегетативного резонансного тесту (ВРТ), використовуючи оптимальний алгоритм діагностики і методику підбору частотних характеристик інформаційних копій гомеопатичних препаратів.

Матеріал і методи. Діагностику і терапію проводили на апаратно-програмному комплексі «ИМЕДИСЭКСПЕРТ». Використовували програмне забезпечення Імедіс-Експерт, версія 6.30, апарат «МИНИ-ЭКСПЕРТ ДТ», апарат «МИНИ-ЭКСПЕРТ Д+», електронний медикаментозний селектор (версія 25 і вище) , апарат для адаптивної біорезонансної терапії «ИМЕДИС-БРТ», матеріали конференцій і з"їздів.

Для пошуку ефективних резонансних препаратів для лікування була використана ідея С. Ганемана про міазми, яка характеризує основні закономірності розвитку і перебігу хронічних захворювань. 3 сучасних позицій міазм можна уявити як чітко детерміновану програму, за якою прогресивно набуває розвитку патологічний процес, незалежно від етіологічного фактора. Вся багатоманітність цієї програми проявляється в конкретних конституційних типах, закладених в патогенез гомеопатичних препаратів. Всі патологічні коливання, виявлені у конкретного хворого, відповідають неоптимальному рівню тієї чи іншої системи органів, тканин, міжкапілярної і міжклітинної рідин, крові, лімфи, клітини, видів обміну, біохімічних показників та інших процесів. Ця неоптимальність характеризує і неоптимальні міазми в даний конкретний відрізок часу. Використовуючи такий підхід через неоптимальні міазми можна підібрати максимально ефективний препарат для конкретного міазму, поступово нівелюючи всі виявлені неоптимальні параметри, і тим самим повернути організм до фізіологічної норми.

Результати. Позитивний результат лікування конкретного пацієнта на основі діагностичних даних, отриманих методом ВРТ, а також результати лікування хворих з іншою патологією підтверджують необхідність ширшого використання методу в клінічній практиці.

Висновки. Метод біорезонансної діагностики і терапії заслуговує на більш широке використання лікарями різних спеціальностей як експрес-метод діагностики. Терапія інформаційними копіями гомеопатичних препаратів дає прогнозовані позитивні результати при вмілому користуванні.

КЛючОВІ СлОВА: рефлексотерапія; біорезонансна діагностика; вегетативний резонансний тест (ВРТ).

Вступ. Більш як 20-річний досвід роботи в галузі інформаційної діагностики і терапії, а також досвід лікаря-рефлексотерапевта дозволяє проаналізувати і зробити деякі висновки за цей період.

Рефлексотерапія, як метод, що має багатовікову історію, стрімко ввірвалася в життя нашої медичної спільноти в кінці 1970 і на початку 1980 років, коли була створена кафедра рефлексотерапії при Київському інституті удосконалення лікарів на чолі з професором Є. Л. Мачерет. У 1977 році розпочалися курси з підготовки лікарів з рефлексотерапії, завдяки чому підготовлено понад 27 тисяч спеціалістів, в тому числі іноземних лікарів, і не тільки з європейських, але й з країн Сходу. В 1980 році була створена служба рефлексотерапії, відкрито мережу кабінетів, у тому числі кабінет рефлексотерапії при Чортківській ЦРЛ. А 9 червня 1993 року був виданий наказ № 130 МОЗ України про затвердження 24 лікарської спеціальності рефлексотерапії.

Майже кожен рефлексотерапевт в своїй роботі зустрічався з проблемами діагностики і підбору акупунктурних точок. Звичайно, існували рецепти і багатовіковий досвід китайської медицини, існува- ла пульсова діагностика, оволодіти якою практично неможливо. Певною новацією стали основи електропунктури, закладені в 1950 роках з появою методу Нкатані (Японія), за яким вимірювання проводились при постійному струмі в 200 мікроампер. Пізніше А. І. Нечушкін зі співавторами запропонували модифікований метод Нкатані, за яким вимірювальний струм був зменшений до 20 мкА і додано вимірювання температури в точках - посібниках.

Другим методом є метод Р. Фоля (Німеччина), при якому струм короткого замикання склав 12 мкА, а через пацієнта - 6 мкА. Полярність на активному електроді позитивна. Такий самий струм зберігається в біофункціональній діагностиці (БФД) і в вегетативно-резонансному тесті (ВРТ), але для підвищення діагностичної чутливості використовується розширення масштабу вимірювальної шкали до 80 ум. од.

До початку 1990 р. для діагностики я використовував методику Нкатані - карту Ріодораку. 3 1990 по 1995 рік користувався методикою Р. Фоля. З 1997 року використовував у своїй роботі метод ВРТ за Шіммелем на апараті фірми ІМЕДІС. 3 2016 року проводжу діагностику на апараті МІHI- 
Огляди літератури, оригінальні дослідження, погляд на проблему, ювілеї

ЕКСПЕРТ -Д+, який дозволяє виявити порушення на 4 рівнях:

- порушення в крові, лімфі, органах, системах органів;

- (зі світлом) - порушення в клітині з клітинною мембраною, протоплазмою, клітинними органелами і мітохондріальною ДНК;

- (зі світлом і поглиначем перешкод) - порушення в ядрі клітини у зовнішній частині ДНК;

- зі світлом, поглиначем перешкод і 50-кратним підсиленням сигналу.

Використовуючи дані методики впродовж тривалого часу можна зробити порівняння різних методів діагностики, таких як ВРТ, з УЗД, комп'ютерною томографією, магнітноядерним резонансом, мікроскопією, методом полімеразно-ланцюгової реакції, діагностикою на генетичному рівні. В переважній більшості випадків дігностичні висновки збігаються. На початку роботи траплялися випадки гіпердіагностики, пов'язані з недосконалістю апаратури, поганою підготовкою хворого та іншими чинниками. Звичайно, траплялися помилки, була присутня деяка суб'єктивність. Про об'єктивність діагностики можна було судити тільки за результатами лікування.

На даному етапі можна сміливо говорити про високу точність і багатопрофільність цього неінвазивного методу діагностики. Метод ВРТ, запропонований Шиммелем в 1978 році, грунтується на ефекті резонансу, що виникає в організмі пацієнта при подачі ззовні певного спектра частот, що відповідають певному патологічному фактору. При наявності аналогічного спектра частот в організмі пацієнта виникає ефект резонансу, проявами якого є зміни опору шкіри, який ми фіксуємо апаратно-програмним комплексом "ІМЕДІС-ФОЛЛЬ". Діапазон діагностичної процедури охоплює як органи, тканини, клітини, їх функції, так і причинні фактори, зокрема такі як геопатогенні, електромангнітні, радіоактивні, психоемоційні, бактеріальні, грибкові, токсичні та інші навантаження. Важливою перевагою методу ВРТ $є$ можливість діагностувати частотні характеристики самого захворювання і визначати причинний ланцюжок проблеми. Даний метод включає великий набір тестів для визначення порушень білкового, вуглеводневого, жирового, водно-сольового обмінів, кислотно-лужної рівноваги, визначення стану імунної системи, рівня імуномедіаторів (90 тестів), амінокислот, гормонів, ензимів, нейромодуляторів і нейротрансміттерів, маркерів метаболізму; визначення неоптимальності продуктів обміну, морфологічних тестів на наявність передінфарктних станів, білкової і вуглеводневої дистрофій, амілоїдозу, фіброзу, тромбозу, склерозу та інших. Цей метод включає і діагностику різних видів алергічних навантажень, контроль на переносимість харчових продуктів, а також діагностику енергетичного стану меридіанів, точок, чакр, п'яти першоелементів. Такий комплексний підхід, разом з класичними методами обстеження, дозволяє діагностувати і лікувати з найбільшою ефективністю. При лікуванні можна використовувати індивідуально підібрані частотні гомеопатичні препарати різних фірм, алопатичні, біорезонансні та інші препарати.

Важливе значення для успішного лікування пацієнта мають детально зібраний анамнез, об'єктивне обстеження, результати лабораторно-клінічних методів, попередня підготовка хворого і емоційний стан самого лікаря.

Оскільки об'єм інформаційно-діагностичних тестів досить значний, то сама апаратна діагностика триває півтори години. Для прикладу наведу алгоритм проведенного обстеження і лікування одного із пацієнтів.

Хвора К., 1965 року народження, зріст 176, вага 85 кг звернулась 28.08.1917 року в кабінет біорезонансної діагностики і терапії зі скаргами на гострий біль в поперековій ділянці хребта з іррадіацією по задньо-боковій поверхні лівого стегна. Гострота болю залежала від положення тіла. Скаржилась на відчуття затерпання в лівій нозі в ділянці сідничного м'яза і паху зліва. Об'єктивно: різко позитивний симптом Ласега, позитивні симптоми Дежеріна, Нері, артеріальний тиск 150 мм. рт. ст. на 90 мм рт. ст.

Згідно з комп'ютерною томографією хребта від 21.04.2017 р. у пацієнтки наявні нерівномірна циркуляторна протрузія L4-S1, циркуляторна протрузія L2-L5 з ознаками спинного звуження лівого міжхребцевого отвору на рівні L5-S1, обох міжхребцевих отворів на рівні L3-L5, правобічний сколіоз 1 ст., хрящові вузли Шморля TH 11, 12, L2, L3, L4; спондилоартроз, остеохондроз поперекового відділу хребта, остеоартроз крижовоклубового з'єднання.

Результати діагностики ВРТ: електромагнітне навантаження 2 ступеня з 4 ступенів важкості, гострий та хронічний стани, вірусна РНК, грампозитивні бактерії, гриби, ревматоїдний артрит, гонартроз, поперековий артроз, нейроінфекції, ревматизм, остеопороз, гіперурикемія, інфекційно-токсичне пошкодження печінки, гепатит A, артеріальна гіпертензія, клімактеричний синдром, міома матки, дисменорея, хронічні дегенеративні інфекції.

Тестувалися: вірус герпесу Епштейна-Барр в потенц. D 5/15/30/60, вірус оперізувального лишаю і вітряної віспи в потенціях D5, D15, D30, D60, D200, D800; герпес простий, дріжджові гриби, невралгії в потенціях D5, D6, D8, D12, D15, D30, D200; патологія корінців спинного мозку, поліартрит 
Огляди літератури, оригінальні дослідження, погляд на проблему, ювілеї

D5-D8, подагра, сечокислий діатез D5-D100, ревмa D5-D12. Також діагностувались органопрепарати в неоптимальному стані: міжхребцеві поперекові суглоби D3-D12, передня поперекова частина хребта D3-D12, поперекові міжхребцеві диски D3D6, передня довгаста зв'язка D3-D6, інфікована лімфа D6-D30, лімфоцити D3-D12, тимус D3-D10, поперекове сплетення D3-D15, крижове сплетення D3-D15, стегновий нерв, сідничний нерв зліва D3-D12, крижово-підздухвинний сугло6 D3-D15, синовіальна мембрана D3-D15, лівий шлуночок серця, атріовентрикулярний пучок, прямокишкове венозне сплетення, підколінна вена, велика підшкірна вена, задня великогомілкова вена, печінка, жовчний міхур, міхурова протока, підшлункова залоза, передня і задня частки гіпофіза, корковий шар правої надниркової залози D3-D6.

Було діагностовано катаболічні процеси 2 ступеня активності, кислотність 3 ступеня у відношенні до всього організму, 5 ступінь бактеріоцидності при нормі 6-го ступеня, кальцифікація, фіброз, рубці, мезенхімна вуглеводна дистрофія, мезенхімна білкова дистрофія, фібриноїдний набряк, мукоїдний набряк. Неоптимальні білковий, вуглеводний, жировий і водно-сольовий обміни. Тестуються гормональні порушення, а саме - не відповідають нормі ендорфін, АКТГ, кортизол, тиреотропін, трийодтиронін, ФСГ, ЛГ, серотонін, простагландин 1, 2, фолікулярна і лютеїнова фази циклу, ангіотензин, імуноглобуліни А, М, Г, ретиноловий комплекс, ЦАМФ 1.2, ЦГМФ 1, адреналін-кейлоновий комплекс. Неоптимальний рівень мали меридіани - лімфатичний, серця, тонкого кишечника, нирки, сечового міхура, перикарда, ендокринний, жовчного міхура, печінки, задньо- і передньосерединні меридіани, а також група чудесних меридіанів.

Пацієнтку перевірено на переносимість частотних характеристик продуктів харчування.

Було визначено максимально пошкоджений меридіан і максимально пошкоджені точки через Цинкум металікум D 60 (при стані гострого запалення переважно тестується надлишок порушеного меридіану).

Частоти виявлених порушень записав на крапельку фізіологічного розчину в першій чашечці медикаментозного селектора протягом 10-15 секунд. Чашечку з записаною інформацією поставив на руку пацієнтки і перевіряв, яким міазмам відповідають ці порушення. В нашому випадку це були міазми Медорінум, Псорінум, Сифілінум, Бацилінум, Вариолінум. Через вказівку визначення домінуючого міазму D60 за Шіммелем знайшов його і відповідно протестував максимально ефективний препарат з мінерального, рослинного чи тваринного царства гомеопатичних препаратів. У нашому випадку це був Ляхезіс в оптимальному розведені С6. Не забираючи препарат Ляхезіс з контуру, знову знайшов домінуючий міазм. I на нього вже тестував відповідну частоту гомеопатичного препарату. І так чинив до тих пір, поки не компенсував всі міззии. Для нашої хворої я підібрав рецепт з таких частотних препаратів: Ляхезіс C6, Нікколлюм металлікум C6, Каліум сульфурікум С6, Арніка С6, Брионія С6. Перевірив цей комплексний рецепт на ефективність компенсації всіх раніше виявлених проблем через вказівку на ефективний медикамент Залізо металічне D26, D800. На розведення C6 організм реагував протягом перших 2,5 годин і продовжував знаходитись на цьому рівні довгий час. Через 2,5 години дав ці самі препарати, але в розведенні С12. Через 4 години дав C30, на яке організм реагував протягом 8 годин. Після цього призначив С50. Треба зазначити, що вже на цьому етапі лікування хвора відчула значне покращення.

У деяких випадках при сильному больовому синдромі можна призначати підібрані алопатичні препарати або зменшувати дозу сумісних раніше призначених препаратів.

При кожному наступному прийомі проводив тестування через Ферум металікум Д 60, шукав частоти органопрепаратів. При цьому перевіряв біохімічні показники і міазми, які відповідають цим порушенням. Нашій хворій я додав ще два препарати : Ацидум фосфорікум і Цинкум пікрінікум в розведені С200, через 1 день після прийому С50. Розведення С 1000 призначив через два дні після прийому С50. Надалі хвору обстежував раз на тиждень. Залежно від ситуації, за весь період лікуванняя призначались і комплексні препаратиБіодиск сом, Вертебра Ком. Інжект - Топас, амінокислота Л - Валін Д 1000, раз в 5 днів, Остеохондрин сом. 2 рази в день. При кожному повторному відвідуванні, при позитивній динаміці, кількість резонансних частотних препаратів значно зменшували. Така закономірність характерна при правильному лікуванні багатьох захворювань. Наша хвора на кінцевому етапі лікування була під навантаженням двох препаратів - Лікоподіум C1000 і Ceкале корнутум С1000. Працездатність відновлена повністю. Рекомендував повторну комп'ютерну томографію хребта, лікувальну гімнастику і відповідне харчування.

3 другої половини XX століття традиційна акупунктура поступово трансформувалась у велику різноманітність методів рефлексотерапії, серед яких біорезонансній діагностиці і терапії належить провідна роль.

Як метод попередньої діагностики, вегетативний резонансний тест (ВРТ) може бути рекомендований для використання в системі сімейної медицини. 
Огляди літератури, оригінальні дослідження, погляд на проблему, ювілеї ЛІТЕРАТУРА

1. Мачерет Е. Л. Основи електро- і акупунктури / Е. Л. Мачерет, А. О. Коркушко. - К. : Здоров'я, 1993.

2. Коваленко О. Е. Рефлексотерапія в Україні; від першоджерел... / О. Е. Коваленко, О.О.Коркушко // Українська Ассоціація Рефлексотерапії та медичної акупунктури.

3. Готовский Ю. В. Электропунктурная диагностика и терапия с применением вегетативного резонансного теста "ИМЕДИС - ТЕСТ +": методические рекомендаци / Ю. В. Готовский, Л. Б. Косарева. - Москва, 2002.

4. Готовский М. Ю. Биорезонансная терапия / М. Ю. Готовский, Ю. Ф. Перов, Л. В. Чернецова. - М. : ИМЕДИС, 2008.

5. Кемпе Н. Учение о миазмах и возможности его использования в биорезонансной терапии / Н. Кемпе // 14 Международная конференция. «Теоретические и клинические аспекты применения биорезонансной и мультирезонансной терапии» : тезисы и доклады (г. Грац, Австрия). - Часть 1. - М., 2008.

6.А. П. Дубров (Институт Рефлексотерапии ФНКЭЦ ТМДиЛ Росздрава. г. Москва. Россия) Проблемные вопросы биорезонансной терапии / А. П. Дубров // 14 Международная конференция. “Теоретические и клинические аспекты применения биорезонансной и мультирезонансной терапии : тезисы и доклады (г. Грац, Австрия). - Часть 1. - М., 2008.

7. Постникова О.А. (Московский гомеопатический центр, кафедра гомеопатии и электропунктурной медицины ИПК ФМБА России, ЗАО “ИНТЕРМЕД") г. Москва, Россия. Тестирование фаз эндокринного цикла у женщин методом ВРТ / О. А. Постникова, Е. В. Постникова // 19 Международная конференция «Теоретические и клинические аспекты применения биорезонансной и мультирезонансной терапии» : тезисы и доклады. - Часть 2. - М., 2013.

8. Самохин В. Практическая электропунктура по методу Р. Фолля. Тестирорование медикаментов, перезапись медикаментов, нозоды и аутонозоды, органоспецифические препараты / В. Самохин. Ю. В. ГотовСКИй. - М. : ИМЕДИС, 1994. - С. 55.

\section{REFERENCES}

1. Macheret, E.L., \& Korkushko, A.O. (1993). Osnovy elektro- $i$ akupunktury [Fundamentals of electrical and acupuncture]. Kyiv. "Zdorovia" [in Ukrainian].

2. Kovalenko, O.E., \& Korkushko, O.O. Refleksoterapiia v Ukraini; vid pershodzherel" [Reflexotherapy in Ukraine; from the primary sources]. Ukrainska Assotsiatsiia Refleksoterapii ta medychnoi akupunktury - Ukrainian Association of Reflexotherapy and Medical Acupuncture [in Ukrainian].

3. Gotovskiy, Yu.V., \& Kosareva, L.B. (2002). Elektropunkturnaya diagnostika i terapiya s primeneniyem vegetativnogo rezonansnogo testa "IMEDIS - TEST +" [Electro-puncture diagnostics and therapy with application of the vegetative resonance test "IMEDIS-TEST + "]. Moscow [in Russian].

4. Gotovskiy, M.Yu., Perov, Yu.F., \& Chernetsova, L.V. (2008). Biorezonansnaya terapiya [Bioresonance therapy]. Moscow: IMEDIS [in Russian].

5. Kempe, N. (2008). Ucheniye o miazmakh i vozmozhnosti yego ispolzovaniya v biorezonansnoy terapii [Teaching about miasma and the possibility of its use in bioresonance therapy]. Teoreticheskiye i klinicheskiye aspekty primeneniya biorezonansnoy i multirezonansnoy terapii-Theoretical and Clinical Aspects of the Use of Bioresonance and Multiresonance Therapy [in Russian].

6. Dubrov, A.P. (2008). Problemnyye voprosy biorezonansnoy terapii [Problematic issues of bioresonance therapy]. Teoreticheskiye i klinicheskiye aspekty primeneniya biorezonansnoy i multirezonansnoy terapii - Theoretical and Clinical Aspects of the Use of Bioresonance and Multiresonance Therapy [in Russian].

7. Postnikova, O.A., \& Postnikova, E.V. (2013). Testirovaniye faz endokrinnogo tsikla u zhenshchin metodom VRT [Testing the phases of the endocrine cycle in women 
Огляди літератури, оригінальні дослідження, погляд на проблему, ювілеї

by ART]. Teoreticheskiye i klinicheskiye aspekty primeneniya biorezonansnoy i multirezonansnoy terapii - Theoretical and Clinical Aspects of the Use of Bioresonance and Multiresonance Therapy [in Russian].

8. Samokhin, V., \& Gotovskiy, Yu.V. (1994). Prakticheskaya elektropunktura po metodu R. Follya. Testirorovaniye medikamentov, perezapis medikamentov, nozody i autonozody, organospetsificheskiye preparaty [Practical electropuncture by the method of $R$. Fall. Testing of medicines, rewriting medications, nosodes and autonosodes, organ-specific drugs]. Moscow: IMEDIS [in Russian].

9. Gotovskiy, Yu.V., Kosarev, L.B., Makhonkin L.B., \& Frolov, L.A. (2002). Elektropunkturnaya diagnostika i terapiya s primeneiiyem vegetativnogo rezonansnogo testa "IMEDISTEST" [Electropuncture diagnostics and therapy with the use of the vegetative resonance test "MEDIS-TEST"]. Moscow: IMEDIS [in Russian].

10. Gotovskiy, Yu.V., Kosareva, L.B., \& Perov, Yu.F. (2002). AMINOKISLOTY [AMINO ACIDS]. Moscow: [in Russian].

11. Gotovskiy, Yu.V., Kosareva, L.B.. Frolova, L.A., \& Perov, Yu.F. (2010). Opioidnyye peptidy, i tkanevyye fiziologicheskiye aktivnyye veshchestva [Hormones, opioid peptides, and tissue physiological active substances]. Moscow: IMEDIS [in Russian].

12. (2013). Programnoye obespecheniye ImedisEkspert 6.30. Elektronnaya biblioteka [Software ImedisExpert 6.30. Digital library]. [in Russian].

13. Kotlyarov, Yu.D., Mikhaylyuta, E.A., Demikhovskaya, E.V., Krasovskaya, A.G., \& Gurgel, L.G. Sravnitelnyy analiz traditsionnykh laboratornykh i biorezonansnykh metodov etiologicheskoy diagnostiki zabolevaniy mochepolo- voy sfery [Comparative analysis of traditional laboratory and bioresonance methods for the etiological diagnosis of genitourinary diseases]. VII Mezhdunarodnaya konferentsiya po biorezonansnoy i multirezonansnoy terapii - VII International Conference on Bioresonance and Multiresonant Therapy [in Russian].

14. Mynosh, B.S. (2007). Deiaki mozhlyvosti vykorystannia vehetatyvnoho rezonansnoho testu $v$ umovakh ambulatornoho pryiomu [Some possibilities of use of vegetative resonance test in the conditions of an outpatient reception]. Materialy II - ho zizdu refleksoterapevtiv Ukrainy prysviachenoho 30-richchiu sluzhby refleksoterapiii v Ukraini - Materials of the 2nd Congress of Reflexologists of Ukraine dedicated to the 30th anniversary of the reflexology service in Ukraine [in Ukrainian].

15. Rodik, I.S., Shevchenko, V.F., \& Fursov, S.E. (1994). Printsipy diagnostiki i terapii zabolevaniy kostno-myshechnoy sistemy na osnove metoda R. Follya [Principles of diagnosis and therapy of diseases of the musculoskeletal system on the basis of the R. Voll method]. Institut Problem Yestestvoznaniya AYEN RF-Institute of Problems of Natural Science AEN RF, 70-77 [in Russian].

16. Mynosh, B.S. (2009). Vehetatyvnyi rezonansnyi test i deiaki yoho diahnostychni mozhlyvosti [Vegetative resonance test and some of its diagnostic possibilities]. Materialy naukovo-praktychnoi konferentsii z mizhnarodnoiu uchastiu. Refleksoterapiia v Ukraini: dosvid i perspektyvy - Materials of the Scientific-practical Conference with International Participation. Reflexotherapy in Ukrvaine: experience and perspectives [in Ukrainian].

\section{ИСПОЛЬЗОВАНИЕ БИОРЕЗОНАНСНЫХ ТЕХНОЛОГИЙ В УСЛОВИЯХ РАЙОННОЙ поликлиники}

\section{Чортковская центральная клиническая районная больница}

๑5. С. Майнош

РЕЗЮМЕ. Цель - сделать краткий обзор развития и трансформации рефлексотерапии в биорезонансную диагностику и терапию в условиях районной поликлиники. На конкретном примере показать отдельные диагностические и терапевтические возможности вегетативного резонансного теста (ВРТ), используя оптимальный алгоритм диагностики и методику подбора частотных характеристик информационных копий гомеопатических препаратов.

Материал и методы. Диагностику и терапию проводили на аппаратно-программном комплексе «ИМЕДИСЭКСПЕРТ». Использовали программное обеспечение Имедис-Эксперт, версия 6.30, аппарат «МИНИ-ЭКСПЕРТ ЗН», аппарат «МИНИ-ЭКСПЕРТ Д+», электронный медикаментозный селектор (версия 25 и выше), аппарат для адаптивной биорезонансной терапии «ИМЕДИС-БРТ», материалы конференций и съездов.

Для поиска эффективных резонансных препаратов для лечения была использована идея С. Ганемана о миазмах, характеризующая основные закономерности развития и течения хронических заболеваний. С современных позиций миазм можно представить как четко детерминированную программу, по которой прогрессивно развивается патологический процесс, независимо от этиологического фактора. Все многообразие этой программы проявляется в конкретных конституционных типах, заложенных в патогенез гомеопатических препаратов. Все патологические колебания, выявленные у конкретного больного, соответствуют неоптимальному уровню той или иной системы органов, тканей, межкапилярной и межклеточной жидкостей, крови, лимфы, клетки, видов обмена, биохимических показателей и других процессов. Эта неоптимальность характеризует и неоптимальные миазмы в данный конкретный отрезок времени. Используя такой подход через неоптимальные миазмы можно подобрать максимально эффективный препарат для конкретного миазма, постепенно нивелируя все выявленные неоптимальные параметры, и тем самым вернуть организм к физиологической норме.

Результаты. Положительный результат лечения конкретного пациента на основе диагностических данных, полученных методом ВРТ, а также результаты лечения больных с другой патологией, подтверждают необходимость более широкого использования метода в клинической практике. 
Огляди літератури, оригінальні дослідження, погляд на проблему, ювілеї

Выводы. Метод биорезонансной диагностики и терапии заслуживает более широкого использования врачами различных специальностей как экспресс-метода диагностики. Терапия информационными копиями гомеопатических препаратов дает прогнозируемые положительные результаты при умелом пользовании.

КЛЮЧЕВЫЕ СЛОВА: рефлексотерапия; биорезонансная диагностика; вегетативный резонансный тест (ВРТ).

\section{USING BIORESONANCE TECHNOLOGIES IN CONDITIONS OF REGIONAL HOSPITAL}

@B. S. Mainosh

\section{Chortkiv Central Clinical District Hospital}

SUMMARY. The aim is to provide a brief overview of the development and transformation of reflexotherapy in bioresonance diagnosis and therapy in a district clinic; on a concrete example, show the individual diagnostic and therapeutic capabilities of the autonomic resonance test (ART), using an optimal diagnostic algorithm and a technique for selecting the frequency characteristics of information copies of homeopathic drugs.

Material and Methods. Diagnostics and therapy was performed on the hardware and software complex "IMEDISEXPERT". The software used by Imedi-Expert, version 6.30, the MINI-EXPERT DT machine, the MINI-EXPERT D + device, the electronic medical selector (version 25 and above), the device for adaptive bioresonance therapy "IMEDIS-BRT", conference materials and congresses.

To find effective resonance medication is for treatment, S. Haneman's idea of miasma was used, which characterizes the basic patterns of development and progression of chronic diseases. From modern positions, miasma can be imagined as a clearly determined program, on which the pathological process progressively acquires, regardless of the etiological factor. All the diversity of this program manifests itself in the specific constitutional types laid down in the pathogenesis of homeopathic remedies. All pathological oscillations found in a particular patient correspond to the suboptimal level of one or another system of organs, tissues, intercapsular and intercellular fluids, blood, lymph, cells, types of metabolism, biochemical parameters and other processes. This neoptimality characterizes and non-optimal miasms in a given specific period of time. Using such an approach through non-optimal miasms it is possible to choose the most effective drug for a specific miasmus, gradually leveling out all revealed suboptimal parameters and thereby returning the organism to the physiological norm.

Results. The positive result of the treatment of a particular patient based on diagnostic data obtained by the method of VRT, as well as the results of treatment of patients with other pathology confirm the need for wider use of the method in clinical practice.

Conclusions. The method of bioresonance diagnosis and therapy deserves more extensive use by doctors of different specialties as an express diagnostic method. Therapy with information copies of homeopathic remedies provides predictable positive results with skillful use.

KEY WORDS: reflexotherapy; bioresonance diagnostic; vegetative resonance test (VRT). 